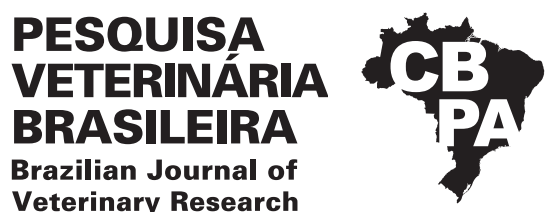

\title{
Assessment of fetal lung maturity using analysis of amniotic fluid from ewes that gave birth prematurely and at term ${ }^{1}$
}

\author{
Natália Cristina de Souza ${ }^{2 *}$ (D) Fernanda Bovino ${ }^{3}$, Larissa Gabriella Avilla ${ }^{4}$, \\ Maurício Deschk ${ }^{5}$, Jefferson F. Alcindo ${ }^{6}$ (D) , Maria Fernanda C.B. Fink ${ }^{7}$, \\ Luiz Cláudio N. Mendes ${ }^{8}$ and Francisco Leydson F. Feitosa ${ }^{8}$
}

\begin{abstract}
Souza N.C., Bovino F., Avilla L.G., Deschk M., Alcindo J.F., Fink M.F.C.B., Mendes L.C.N. \& Feitosa F.L.F. 2020. Assessment of fetal lung maturity using analysis of amniotic fluid from ewes that gave birth prematurely and at term. Pesquisa Veterinária Brasileira 40(12):1039-1047. Departamento de Clínica, Cirurgia e Reprodução Animal, Faculdade de Medicina Veterinária de Araçatuba, Universidade Estadual Paulista, Rua Clóvis Pestana 793, Cx. Postal 533, Jardim Dona Amélia, Araçatuba, SP 16050-680, Brazil. E-mail: souzanataliancs@gmail.com

The aim of this study was to evaluate the lung maturity of premature and full-term lambs by analyzing amniotic fluid using the following methods: Clements test, Nile blue cytology test, hematoxylin-Shorr stain, lamellar body count, and radiographic tests. The use of these methods is intended to identify high-risk newborns and provide immediate clinical intervention after birth. Altogether, 56 animals (24 ewes and 32 lambs) were included in the study and divided into 3 groups. Group I consisted of 8 ewes that were at approximately 145 days of gestation; this group delivered 10 lambs naturally. Group II consisted of 8 ewes that were at 138 days' gestation; this group delivered 11 lambs by cesarean section. Group III consisted of 8 ewes at 138 days' gestation; this group was administered intramuscular dexamethasone (16mg/animal) 36 hours prior to a cesarean section. Group III delivered11 lambs. Cytological tests were performed using a microscope with a maximum magnification of $1000 x$, while the Clements test was visually observed by one of the researchers. Amnioticfluid lamellar body counts were measured using transmission electron microscopy. Among the staining methods, hematoxylin-Shorr was reliable, and Group III had a greater number of orangeophilic cells when compared to Group II, probably due to corticoid administration. The Clements test showed pulmonary maturity in approximately $20 \%$ of Group I lambs and Group II showed $9.1 \%$ of bubbles; however, Group III had the highest pulmonary maturity percentage (36.4\%). The lamellar bodies were measured, and all groups had sizes between 0.019 and $0.590 \mu \mathrm{m}$. Radiographic evaluation revealed that the majority of lambs presented some level of pulmonary radiodensity, indicating an acinar pattern at birth. These results are in line with the expectations of each group. We found that the normal group showed greater pulmonary maturity, whereas Group II presented pulmonary immaturity, which is expected because this group comprised lambs born prematurely and Group III showed pulmonary
\end{abstract}

\footnotetext{
${ }^{1}$ Received on August 17, 2020.

Accepted for publication on September 10, 2020.

${ }^{2}$ Graduate Program in Animal Science, Departamento de Clínica, Cirurgia e Reprodução Animal, Faculdade de Medicina Veterinária, Universidade Estadual Paulista "Júlio de Mesquita Filho" (Unesp), Campus Araçatuba, Rua Clóvis Pestana 793, Jardim Dona Amélia, Araçatuba, SP 16050-680, Brazil. *Corresponding author: souzanataliancs@gmail.com

${ }^{3}$ Professor, Faculdade de Ciências Agrárias Andradina (FCAA), Fundação Educacional de Andradina (FEA), Rua Amazonas 571, Stella Maris, Andradina, SP 16901-160SP, Brazil.

${ }^{4}$ Professor, Universidade Federal de Mato Grosso do Sul (UFMS), Cidade Universitária, Av. Costa e Silva s/n, Pioneiros, Campo Grande, MS 79070-900, Brazil.
}

\footnotetext{
${ }^{5}$ Veterinarian, Universidade Federal de Juiz de Fora (UFJF), Campus Universitário, Rua José Lourenço Kelmer s/n, São Pedro, Juiz de Fora, MG 36036-900, Brazil.

${ }^{6}$ Professor, Universidade Federal de Juíz de Fora (UFJF), Campus Universitário, Rua José Lourenço Kelmer s/n, São Pedro, Juiz de Fora, MG 36036-900, Brazil.

${ }^{7}$ Graduation in Veterinary Medicine, Faculdade de Medicina Veterinária, Universidade Estadual Paulista "Júlio de Mesquita Filho" (Unesp), Campus Araçatuba, Rua Clóvis Pestana 793, Jardim Dona Amélia, Araçatuba, SP 16050-680, Brazil.

${ }^{8}$ Professor, Departamento Clínica, Cirurgia e Reprodução Animal, Faculdade de Medicina Veterinária, Universidade Estadual Paulista "Júlio de Mesquita Filho" (Unesp), Campus Araçatuba, Rua Clóvis Pestana 793, Jardim Dona Amélia, Araçatuba, SP 16050-680, Brazil.
} 
maturity almost comparable to the normal delivery group (Group I). This is due to the fact that although these animals are premature, the use of dexamethasone helped in pulmonary maturation. Therefore, these pulmonary maturity tests are considered effective when more than one technique is used and can be used routinely in the care of a pregnant ewe in labor, where a simple collection of amniotic fluid can predict a high-risk pregnancy and alert the veterinarian if the newborn needs intensive supportive treatment.

INDEX TERMS: Fetus, lung, amniotic fluid, ewes, sheep, lung fetal maturity, lamb survival, ovine.

RESUMO.- [Avaliação da maturidade pulmonar feta
utilizando a análise de líquido amniótico de ovelhas
que deram à luz prematuramente e a termo.] 0 objetivo deste estudo foi avaliar a maturidade pulmonar de cordeiros prematuros e a termo por meio da análise do líquido amniótico utilizando os seguintes métodos: teste de Clements, teste de citologia do azul do Nilo, coloração de hematoxilina-Shorr, contagem de corpos lamelares e testes radiográficos. Um desses métodos tem por objetivo identificar recém-nascidos de alto risco e fornecer intervenção clínica imediata após o nascimento. Ao todo, 56 animais ( 24 ovelhas e 32 cordeiros) foram incluídos no estudo e divididos em 3 grupos. 0 grupo I foi composto por 8 ovelhas com aproximadamente 145 dias de gestação; este grupo deu à luz 10 cordeiros naturalmente. 0 Grupo II foi composto por 8 ovelhas com 138 dias de gestação; este grupo deu à luz 11 cordeiros por cesariana. Grupo III consistiu de 8 ovelhas com 138 dias de gestação; este grupo recebeu dexametasona intramuscular (16 mg / animal) 36 horas antes de uma cesariana. 0 Grupo III entregou 11 cordeiros. Os testes citológicos foram realizados em microscópio com aumento máximo de 1000x, enquanto o teste de Clements foi observado visualmente por um dos pesquisadores. A contagem de corpos lamelares de líquido amniótico foi medida usando microscopia eletrônica de transmissão. Dentre os métodos de coloração, o hematoxilina-Shorr foi confiável, sendo que o Grupo III apresentou maior número de células orangeofílicas quando comparado ao grupo II, provavelmente devido à administração de corticóide. 0 teste de Clements mostrou maturidade pulmonar em aproximadamente $20 \%$ dos cordeiros do Grupo I e o Grupo II apresentou 9,1\% de bolhas; entretanto, o Grupo III apresentou o maior percentual de maturidade pulmonar $(36,4 \%)$. Os corpos lamelares foram medidos e todos os grupos apresentaram tamanhos entre 0,019 e $0,590 \mu \mathrm{m}$. A avaliação radiográfica revelou que a maioria dos cordeiros apresentava algum grau de radiodensidade pulmonar, indicando padrão acinar ao nascimento. Esses resultados estão alinhados com as expectativas de cada grupo. Verificamos que o grupo normal apresentou maior maturidade pulmonar, enquanto o Grupo II apresentou imaturidade pulmonar, o que é esperado por se tratar de cordeiros nascidos prematuramente e o Grupo III apresentou maturidade pulmonar quase comparável ao grupo de parto normal (Grupo I). Isso se deve ao fato de que, embora esses animais sejam prematuros, o uso da dexametasona auxiliou na maturação pulmonar. Portanto, esses testes de maturidade pulmonar são considerados eficazes quando mais de uma técnica são utilizadas e podem ser usadas rotineiramente no cuidado de uma ovelha gestante em trabalho de parto, onde uma simples coleta de líquido amniótico pode prever uma gravidez de alto risco e alertar o veterinário se o recémnascido precisa de tratamento de suporte intensivo.

TERMOS DE INDEXAÇÃO: Pulmão, feto, líquido amniótico, ovelhas, maturidade pulmonar fetal, sobrevivência de cordeiros.

\section{INTRODUCTION}

Neonatology in farm animals is an area with little advancement. In human pediatrics, due to advances in technology and the adequate supportive treatment of premature newborns, the likelihood of survival for these high-risk patients is easily achieved; premature babies under 28 weeks can survive (Patel 2016, Cheong et al. 2018).

The reverse occurs in veterinary medicine; whereas the gestation period in sheep varies between 145 to 148 days (Jainudeen \& Hafez 2004) and this period can be modified by maternal, fetal and environmental factors. In other words, lambs born just 7 days before the expected date of delivery are at great risk of dying, even before the first 24 hours of life. Therefore, according the some studies, lambs born with an average of 138 days can be considered premature (Radostits et al. 2007, Avila et al. 2014, Bovino 2015, Feitosa et al. 2017, Miura et al. 2019).

In premature human neonates, one of the primary assessments is lung function, since this function is essential for the survival of the newborn and lung development problems can cause complications, such as respiratory distress syndrome (RDS) among others (Ghartey et al. 2012, Harrison \& Goldenberg 2016, Patel 2016).

Based on these data, we must have the same concerns with animal species, and lung function must be assessed since prematurity can lead to impaired lung capacity in premature lambs. One of the important assessments that can be applied right after lamb birth is the Apgar score modified by Born (1981). It is a method that assesses the animals' vitality level through some parameters at birth (Rodrigues et al. 2007, Avila et al. 2014).

In human medicine, the evaluation of amniotic fluid is important in determining the fetal condition. A variety of biochemical, cytological, immunological and biophysical tests can be performed using amniotic fluid to assess pulmonary, renal, and epidermal maturation (Kjeldsberg \& Knight 1998, Miron 2012). However, some of these methods have disadvantages such as delay in results, requiring specialized training and are considered expensive (Dubin 1998).

As an alternative in human medicine, the Clements test, lamellar body counts, and Nile blue cytology are fast, cheap, and routine methods that can determine whether the fetus is premature. The Clements test is a qualitative method used to determine the presence of pulmonary surfactant contained in the amniotic fluid (Clements et al.1972, Crockett 1988).

Lamellar bodies store surfactant, which is then released into the alveolar space by fetal breathing movements (Dubin 1998, Jörger et al. 2017). As for the cytological method of Nile blue, the amniotic fluid is rich in epithelial cells originating from the skin and other fetal constituents. The classification of these cells can indicate immaturity or maturity of the fetal epidermis (Rosborg 1970, Morrison 1974, Souza et al. 2000). 
Due to the advantages of these methods, there are some studies described in animal species that assessed fetal lung maturity through the analysis of amniotic fluid, including the physical and biochemical analysis of amniotic fluid in sheep (Souza et al. 2000); the use of cytological typification of amniotic fluid at the time of calving (Moya 2005); the analysis of amniotic fluid in neonate horses including the use of lamellar body counts to assess fetal lung maturity (Castagnetti et al. 2007); the evaluation of the efficiency of the Clements test, of the Nile blue cytology and Shorr and lamellar bodies count in the amniotic fluid of goats born by eutocic and premature births (Feitosa et al. 2020).

Since gestational complications such as prematurity are associated with higher mortality rates, directly affecting the productivity of a herd, the use of rapid and routine methods to support these newborns is extremely important, since neglect in treatment of a newborn can cause several economic losses to the producer.

The aim of this study was to assess the degree of vitality, as well as the pulmonary maturity of premature and fullterm lambs through the analysis of amniotic fluid, using the Clements test, lamellar body count, and Nile blue cytology, allowing better identification of high-risk newborn lambs and providing immediate clinical intervention after birth.

\section{MATERIALS AND METHODS}

Experimental group. A total of 56 animals (24 multiparous ewes and 32 lambs) from a Suffolk crossbreed flock in Araçatuba, São Paulo State, were included in the study. The ewes were divided into 3 experimental groups. Group I consisted of 8 ewes at approximately 145 days gestation. This group produced 10 lambs born naturally. Group II consisted of 8 ewes at 138 days gestation. This group delivered 11 lambs by caesarean section. Group III consisted of 8 ewes at 138 days gestation which were administered intramuscular dexamethasone (16 mg/animal) 36 hours prior to caesarean section. Group III had 11 lambs.

The ewes were left to graze on pasture with corn based silage and other supplements provided to ensure a balanced diet. Prior to their expected due date and/or scheduled cesarean section, the ewes were transferred to a stall in order to enable observations. Group I ewes were monitored 24 hours a day so that adequate support could be given in case of lambing.

To assist animal management on this study and to ensure lambing happened in a condensed time frame, a protocol for the fertilization of the ewes was developed. Estrus was synchronized using vaginal sponges impregnated with progesterone, followed by an intramuscular administration of $0.4 \mathrm{~mL}$ of prostaglandin (PGF $2 \alpha$ ) on day 0 (D0). This procedure was followed by an intramuscular administration of 500IU of equine chorionic gonadotropin (eCG) and $0.4 \mathrm{~mL}$ of prostaglandin on the day 7 (D7). A misture of ink and oil was placed on the breast region of the breeding ram. So when the male covered the female, it was possible to see a paint stain on the rear of the sheep, a different color was used every 15 days, in order to differentiate the females who returned to heat. This type of marking allowed us to facilitate the observation of the females that were covered and from the day of covering it was possible to estimate individual fertilizations dates, and later the pregnancies confirmed using an ultrasound (DP Vet 2200, Mindray) scan 45 to 60 days post fertilization.

For the cesarean sections conducted, the anesthetic procedure used included a proximal paravertebral block, which consisted of $5 \mathrm{~mL}$ of lidocaine hydrochloride ( $2 \%$ Xylestesin ${ }^{\circledR}$, Cristália) administered in each dorsal and ventral nerve roots of T13, L1, and L2 combined with epidural administration (L6-S1) of morphine sulfate (Dimorf ${ }^{\circledR}$, Cristália) at a dose of $0.1 \mathrm{mg} / \mathrm{kg}$ diluted in $5 \mathrm{~mL}$ of saline. In cases where the paravertebral anesthesia was not considered effective, lidocaine hydrochloride was used directly at the incision site. After the removal of the fetus, the ewes were sedated using midazolam maleate (Dormonid ${ }^{\circledR}$, Roche) at a dose of $0.2 \mathrm{mg} / \mathrm{kg}$. The caesarean sections were conducted by an incision on the ewes left flank, while they were placed in right lateral decumbency, as described (Tibary \& Van Metre 2004).

Amniotic fluid (sample collection). In ewes that delivered naturally (Group I), AF was collected after the expulsion of the amniotic sac. If the amniotic sac remained intact, this was done by puncturing the sac using an 18G hypodermic needle attached to a 20 -mL syringe. If the amniotic sac had ruptured, AF was obtained by placing a "Falcon" tube next to the vulva while the ewe was having contractions. After samples had been taken, the AF samples were kept refrigerated in Styrofoam containers with ice packs. They were then subsequently frozen at $-18^{\circ} \mathrm{C}$. For Groups II and III, the ewes uterus was first exteriorized in order to establish the best place for uterine incision. This avoided excessive bleeding and contamination of AF with blood from the cesarean section. Once the placenta could be observed, the amniotic sac was gently ruptured, and an 18G hypodermic needle coupled to a 20 -mL syringe was used to harvest the largest amount of amniotic fluid possible. All the AF samples collected from the 3 groups were evaluated using the same tests, the Clements' test, lamellar body count, and $0.1 \%$ Nile blue and hematoxylin-Shorr staining.

Lamb vitality. To evaluate the vitality of the lambs, the Apgar score modified by Born (1981) was used. This included the following items scored from 0 to 2 : a) response to cold water on the head (0 = absent, 1 = decreased, 2 = spontaneous and active movements); b) palpebral and interdigital reflex ( $0=$ absent; 1 = weak reaction, one reflex present; 2 = immediate reaction, both reflexes present); c) Respiratory activity ( $0=$ imperceptible, $1=$ slow and irregular, $2=$ regular and rhythmic); d) mucous membrane color ( $0=$ white or blue, 1 = blue-tinged, 2 = pink-red). The scores were then interpreted using a grading system. A score between 7 and 8 represented good vitality, 4 to 6 was considered moderate vitality, and 0 to 3 was considered low vitality (depressed). Apgar evaluation has been widely used as a routine method in newborn lambs and goats (Feitosa et al. 2020, Avila et al. 2014). Lambs belonging to Groups II and III were closely monitored and bottle-fed $(50 \mathrm{ml})$ where possible with colostrum harvested from their mothers. Later, the lambs were put in individual stalls $\left(9 \mathrm{~m}^{2}\right)$ with their mothers and observed to see whether they would be accepted by their mother. None of the premature lambs were rejected by their mother. Care was taken to ensure that the temperature and ventilation was at a level to prevent hypothermia and hypoxia of the neonates. Temperature was controlled using an incubator and ventilation was controlled using an Ambu bag.

Mortality rates. The mortality rate of newboen lambs was expressed as a percentage in this study, some lambs that died were submitted to necropsy to diagnose the possible cause of the death.

Pulmonary radiography evaluation. The pulmonary radiographic examination was performed at lambs birth (M0), at 24 (M24) and 48 hours of life (M48), using a fixed X-ray device, placing the animals in the lateral decubitus position side.

Clements's test. Clements' test was performed using the guidelines set out previously (Clements et al. 1972). Five different dilutions of AF in $14 \times 100 \mathrm{~mm}$ glass tubes, that had been chemically 
cleaned with ether, were distributed differing amounts of $\mathrm{AF}$, saline $(0.9 \%=\mathrm{S})$, and ethanol $(95 \%=\mathrm{E})$. Tube 1 consisted of $1 \mathrm{~mL}$ of AF and $1 \mathrm{~mL}$ of $\mathrm{E}$; Tube 2 consisted of $0.75 \mathrm{~mL}$ of $\mathrm{AF}, 0.25 \mathrm{~mL}$ of $\mathrm{S}$, and $1 \mathrm{~mL}$ of E; Tube 3 consisted of $0.5 \mathrm{~mL}$ of AF, $0.5 \mathrm{~mL}$ of $\mathrm{S}$, and $1 \mathrm{~mL}$ of E; Tube 4 consisted of $0.25 \mathrm{~mL}$ of $A F, 0.75 \mathrm{~mL}$ of $\mathrm{S}$, and $1 \mathrm{~mL}$ of $\mathrm{E}$; and tube 5 consisted of $0.2 \mathrm{~mL}$ of $\mathrm{AF}, 0.8 \mathrm{~mL}$ of $\mathrm{S}$, and $1 \mathrm{~mL}$ of $\mathrm{E}$. All the tubes were closed using a clean rubber stopper, vigorously shaken for 15 seconds, and then placed in an upright rack. After 15 minutes, if there was an intact ring of bubbles at the air/liquid interface, this was considered to be a positive result. For this test, outcomes were divided into two categories: (1) negative or "immature": nonpersistent bubbles in the first tube and persistent in the first and second tubes but not in the third and (2) positive or "mature": stable foam in the first 3 tubes.

Lamellar body count. The LB count was performed using platelet channel hematology analyzers, utilizing $0.5 \mathrm{~mL}$ of AF per sample. The equipment was calibrated using the parameters for platelet count in sheep, which is 25 to 35 fentiliters. The samples were filtered, placed in tubes measuring $12 \times 75 \mathrm{~mm}$, and the supernatant tested using an automated Coulter STKS ${ }^{\circledR}$ platelet channel. They were assessed by size and volume distribution, and compared to a standard logarithmic curve -carrier flow technology (Fakhoury et al. 1994, Carrillo et al. 1997, Lewis et al. 1999).

Nile blue staining. For the Nile blue staining, approximately $50 \mu \mathrm{l}$ of AF was placed on a microscope slide, on which $50 \mu \mathrm{l}$ of a $0.1 \%$ Nile blue sulfate solution was added. The solutions were mixed together and mounted underneath a coverslip in order to facilitate visualization. The cells derived from $\mathrm{AF}$ were observed under a light microscope (at a magnification of 400 to 1,000 X). The cells were classified as either cyanophilic (blue cells) which indicates immature fetal cells or orangeophilic (orange cells), which indicates fetal cell maturity (Brosens \& Gordon 1966).

Hematoxylin-Shorr staining. For the hematoxylin-Shorr staining samples that contained mucus were placed in a centrifuge at 3,000 rpm for 3 minutes in order to avoid cell lysis. Following this the sample went through a cytospin. Mucus-free samples were directly placed in a cytocentrifuge $\left(\mathrm{REVAM}^{\circledR}\right)$ at $1000 \mathrm{rpm}$ for 6 minutes. Sample staining was performed according to the recommendations published in previous studies. The cells too were classified as either cyanophilic (blue cells) which indicates immature fetal cells or orangeophilic (orange cells), which indicates fetal cell maturity (Luna 1968,).

Statistical analysis. Data were analyzed for variance using the SAS PROC MIXED (Statistical Analysis System) and covariance structure as defined by Akaike's information criterion. Means were compared multiple times using LSMEANS (Least Squares Means), which was adjusted to Tukey's test. The values of variables (tables with medians) were analyzed using Kruskal-Wallis test. This was done in order to progressively compare the groups. The Friedman test was used to compare times in each group. This was followed by Dunn's multiple comparisons test. The values of each of the variables, the color of the mucous membrane and the results of the Clements' test were analyzed using Fisher's exact test. The significance level was set at $5 \%$.

All procedures such as the administration of anesthetic and conducting a cesarean section were carried out by the same people. Similarly, rating and analyses, whether radiological, laboratory-based, or clinical, were always carried out by the same people on the team.

Research ethics commission. This study was conducted with the approval of the Ethics Committee on Animal Use of the "Faculdade de Medicina Veterinária”, Unesp, City of Araçatuba, São Paulo, Brazil (protocol FOA-00121-2013).

\section{RESULTS}

\section{Apgar score}

In our study, the lambs belonging to Group I, showed statistical difference $(p<0.05)$ in the moments immediately after birth (T0) and 15 minutes after birth (T15), showing greater vitality, reaching the highest Apgar score (score 8) when compared to Group II and III. However, it is possible to visualize in Groups II and III, although there are no significant differences, the Group III showed better vitality at birth (T0) than Group II ( $3 \pm 2.38$ and $5 \pm 1.5$, respectively), and after 15 minutes after birth (T15) the values were equal (Table 1).

\section{Mortality rates}

None of the lambs born at term (Group I) died. Although the groups did not differ statistically, in prematurely born lambs, the mortality rate, as expected, was high. This was especially the case for lambs delivered by ewes that did not receive dexamethasone 36 hours before the cesarean section was performed (Group II). In this group, $4(4 / 11=36 \%$ ) newborns died within 15 minutes of birth and two more died between 15 minutes and 12 hours after birth. Of the premature lambs born from ewes that received a 16-mg dose of dexamethasone (Group III), a total of 3 animals died (3/11 $=27 \%$ ), two of them within 15 minutes (T15) and the third within one hour (T60). The dead lambs were submitted to a necropsy examination and hydrostatic docimasia of Galen was performed to prove that lung failure had occurred in animals that died in the first 15 minutes after birth. Necroscopic findings for the lambs that died up until 12 hours after birth were congestion and diffuse edema in both lungs and liver.

Table 1. Evaluation of the Apgar score modified by Born (1981) at birth (T0), and at 15 and 60 minutes after birth, with scores from 0 to 3 (low vitality), 4 to 6 (moderate vitality) and 7 to 8 (good vitality) in lambs born naturally (Group I), premature and caesarean section (Group II), premature and cesarean section + dexamethasone (Group III)

\begin{tabular}{|c|c|c|c|c|c|c|c|c|c|}
\hline \multirow{3}{*}{ Timepoints } & \multicolumn{9}{|c|}{ Apgar } \\
\hline & \multicolumn{3}{|c|}{ Group I } & \multicolumn{3}{|c|}{ Group II } & \multicolumn{3}{|c|}{ Group III } \\
\hline & $\mathrm{n}$ & $\mathrm{Md}$ & Min-Max & $\mathrm{n}$ & $\mathrm{Md}$ & Min-Max & $\mathrm{n}$ & $\mathrm{Md}$ & Min-Max \\
\hline T0 & 10 & $8^{a}$ & $6-8$ & 11 & $3^{b}$ & $0-7$ & 11 & $5^{b}$ & $2-7$ \\
\hline $\mathrm{T} 15$ & 10 & $8^{a}$ & $6-8$ & 7 & $6^{b}$ & $1-7$ & 10 & $5^{b}$ & $1-8$ \\
\hline T60 & 10 & 7 & $6-8$ & 5 & 6 & $6-8$ & 8 & 6 & $5-8$ \\
\hline
\end{tabular}

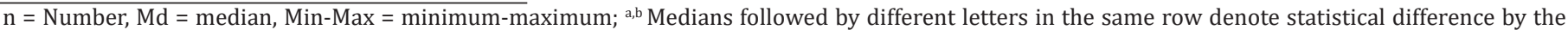
Dunn test $(\mathrm{p}<0.05)$. 


\section{Pulmonary radiography evaluation}

On radiographic evaluations of Group I lambs immediately following birth (M0), most lambs showed increased pulmonary radiodensity along with an alveolar pattern in their diaphragmatic lobes (Fig.1A). Some lambs, however, showed no breathing pattern changes.

For 7 of the lambs in Group II, there was a homogeneous increase in pulmonary radiodensity, which obscured the view of the cardiac silhouette. This is consistent with pleural effusion, which is associated with difficulty in viewing the diaphragmatic dome. A general increase in pulmonary radiodensity with alveolar pattern and the presence of air bronchograms in diaphragmatic lobes was observed in lambs. In these cases, the cardiac silhouette and diaphragmatic domes could be partially seen due to the intense alveolar pattern (Fig.1B). Such results have also been reported in humans, where radiographic findings show that the surfactant deficiency in RDS causes a generalized acinar collapse; thus, decreased lung expansion as well as thinning of the pulmonary vessels and air bronchograms are observed (Agrons et al. 2005).

Three lambs born by cesarean section, whose mothers received dexamethasone 36 hours prior (Group III), showed a slight increase in radiodensity with an alveolar pattern in the diaphragmatic and accessory lobes, with blurring of the caudal vena cava observed. Eight lambs displayed homogeneous radiodensity in their thoracic cavity, which obscured the cardiac silhouette and diaphragmatic domes from view. This suggested the occurrence of atelectasis in these lambs (Fig.1C).

\section{Clements' test}

Although it was expected that AF of ewes belonging to Group I would show the greatest bubble stability as they were born at term (Table 2), there were no statistical differences between groups $(p<0.05)$. Bubbles were observed up to the third tube for one ewe from Group II (Fig.2A,B). The AF obtained from 4 ewes in Group III showed a higher percentage of lung maturity (36.4\% out of a total of 11 animals) also contained bubbles.

\section{Lamellar body count}

Using transmisssion electron microscopy (TEM), we observed that females in Groups II and III had a greater absence of lamellar bodies in the amniotic fluid when compared to fullterm sheep (Fig.3). We found that the sheep lamellar bodies belonging to Group III showed variation in the measurements, with the smallest measurement being 0.019 to the largest of $0.590 \mu \mathrm{m}$, while the size of the lamellar bodies of Groups I and
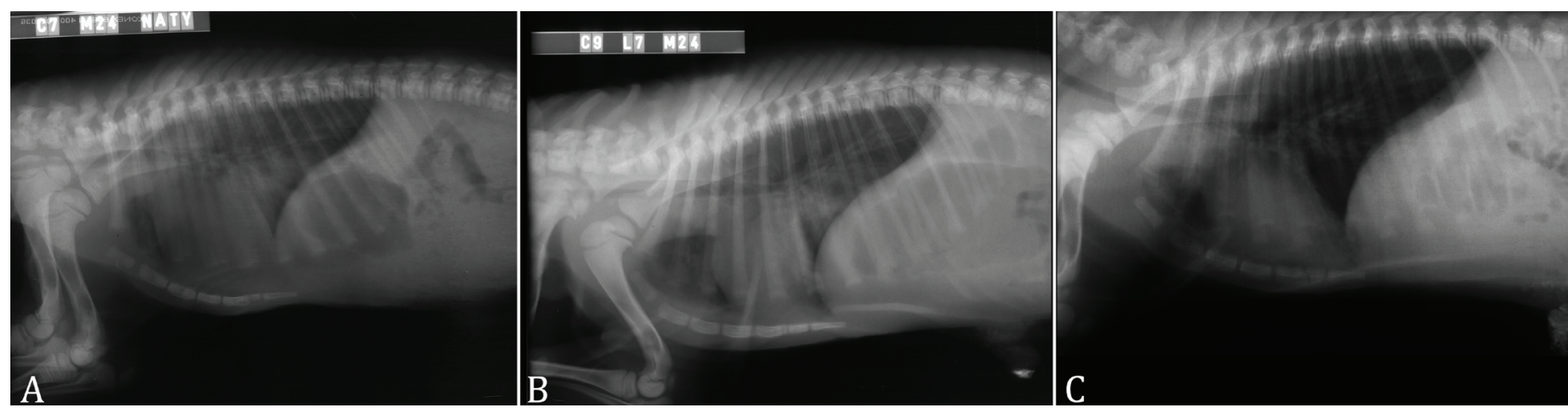

Fig.1. (A) Radiograph showing respiratory pattern of lambs born in a normal birth (Group I). Increased pulmonary radiopacity of the alveolar pattern located in diaphragmatic lobes at 24 hours after birth (M24). (B) Toracic radiograph of cesarean section lambs (Group II) at 24 hours(M24) after birth, denotes a general increase in pulmonary radiodensity with alveolar pattern and the presence of air bronchograms in diaphragmatic lobes was observed in lambs. In these cases, the cardiac silhouette and diaphragmatic domes could be partially seen due to the intense alveolar pattern. (C) Toracic radiograph of lambs born by cesarean section + dexamethasone (Group III) in 24 hours (M24) after birth, the lambs displayed homogeneous radiodensity in their thoracic cavity, which obscured the cardiac silhouette and diaphragmatic domes from view. This suggested the occurrence of atelectasis in these lambs.

Table 2. Number (n) and percentage (\%) of the Clements' test in amniotic fluid of ewes belonging to Groups I, II and III. Results are classified as positives (presence of bubbles), indicative of fetal lung maturity, or negative (absence of bubbles), indicating fetal lung immaturity

\begin{tabular}{|c|c|c|c|c|c|c|c|c|}
\hline \multirow{2}{*}{ Tube } & \multirow{2}{*}{ Clements' test } & \multicolumn{2}{|c|}{ Group I } & \multicolumn{2}{|c|}{ Group II } & \multicolumn{2}{|c|}{ Group III } & \multirow{2}{*}{$\mathrm{P}^{\mathrm{a}}$} \\
\hline & & $\mathrm{n}$ & $\%$ & $\mathrm{n}$ & $\%$ & $\mathrm{n}$ & $\%$ & \\
\hline \multirow[t]{2}{*}{$1 \mathrm{st}$} & Positive & 2 & 20.0 & 1 & 9.1 & 4 & 36.4 & 0.3313 \\
\hline & Negative & 8 & 80.0 & 10 & 90.9 & 7 & 63.6 & \\
\hline \multirow[t]{2}{*}{$2 \mathrm{nd}$} & Positive & - & - & 1 & 9.1 & 2 & 18.2 & 0.7560 \\
\hline & Negative & 10 & 100.0 & 10 & 90.9 & 9 & 81.8 & \\
\hline \multirow[t]{2}{*}{$3 r d$} & Positive & - & - & 1 & 9.1 & - & - & 1.0000 \\
\hline & Negative & 10 & 100.0 & 10 & 90.9 & 11 & 100.0 & \\
\hline 4 th & Negative & 10 & 100.0 & 11 & 100.0 & 11 & 100.0 & - \\
\hline 5 th & Negative & 10 & 100.0 & 11 & 100.0 & 11 & 100.0 & - \\
\hline
\end{tabular}

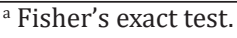


II remained within the values found in Group III. This explains why counting LB in commercial hematological counters is difficult, as sheep LB are much smaller than platelets. As the exact counting of lamellar bodies was not possible, lamellar bodies were measured to clarify their size and the comparison between groups was observacional.

\section{Nile blue staining}

In cytological analysis using Nile blue staining, we found that Group I showed no significant difference in the observation of blue and orange-stained cells compared with Group II. We did, however, observe a statistically significant difference between Groups I and III $(p<0.05)$. In the majority of amniotic fluids studied (Table 3), there were more blue-stained cells compared to orange-stained cells. Groups I, II, and III had medians of $96.1 \%, 90.5 \%$, and $87 \%$ respectively.

\section{Hematoxylin-Shorr}

In contrast to the results obtained using the Nile blue test, in which a high number of blue cells were observed, the hematoxylin-Shorr method showed a higher number of orange-stained cells (Table 3). The number of these orangestained cells, which is indicative of fetal maturity was lower in Groups II (Fig.4B) and III (cesarean + dexamethasone) (Fig.4C), as compared to the samples obtained from ewes that delivered naturally (Fig.4A). Table 3 shows a significant difference $(p<0.05)$ between Group I when compared to Group III. The Groups I, II and III had medians of 79.0\%, 60.0\% e $54.4 \%$ of orange cells indicative of fetal maturity, respectively.
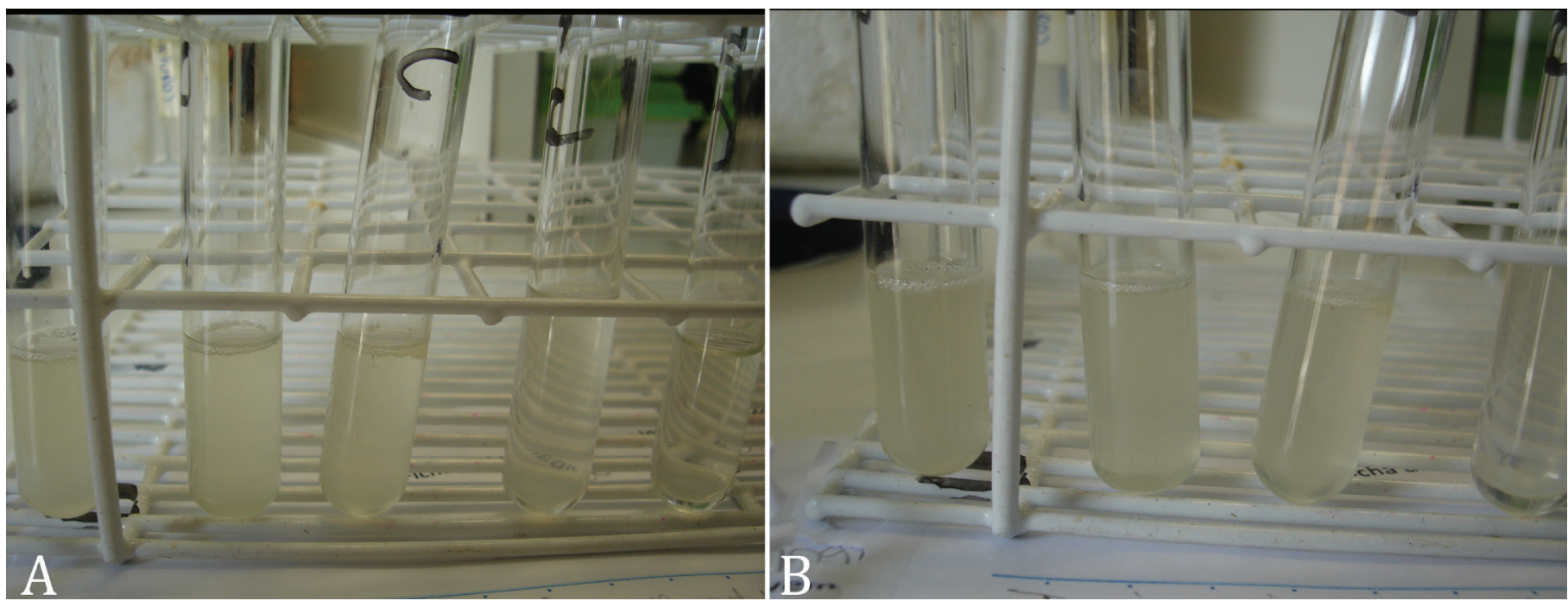

Fig.2. (A) Presence of bubbles observed up to the third tube for one ewe from Group II (Caesarian section). (B) Maturity pulmonary fetal. If there was an intact ring of bubbles at the air/liquid interface, this was considered to be a positive result; were divided into two categories: (1) negative or "immature": non-persistent bubbles in the first tube and persistent in the first and second tubes but not in the third and (2) positive or "mature": stable foam in the first 3 tubes.
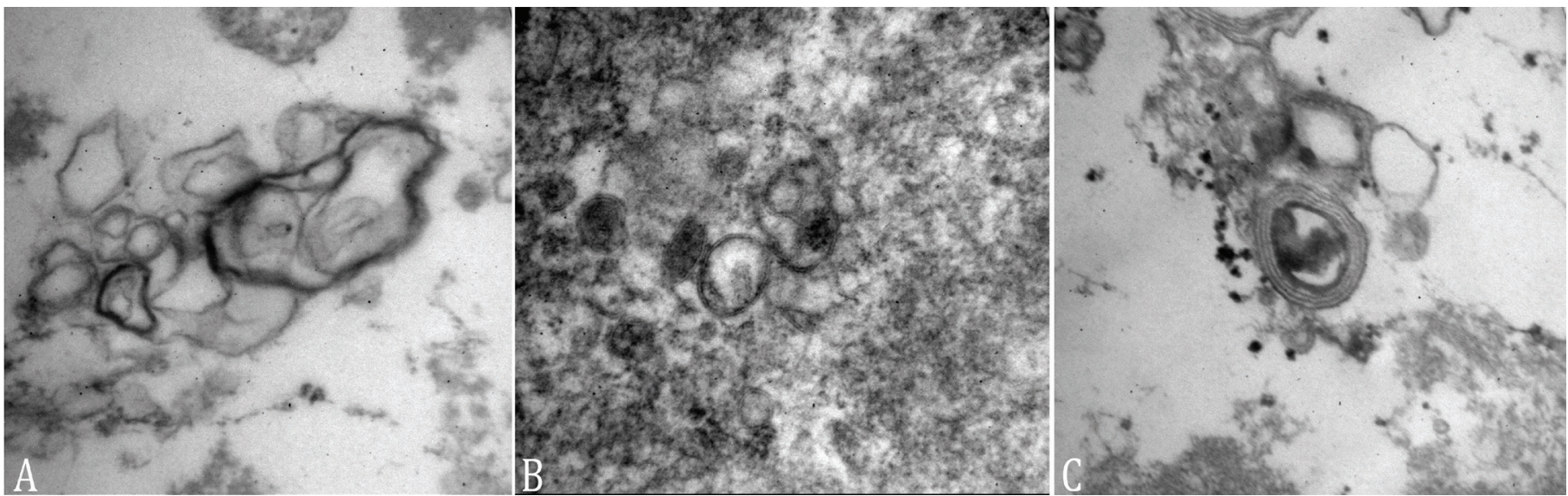

Fig.3. (A) Presence of lamellar bodies in amniotic fluid from sheep belonging to Group I (born naturally), in an increase of 75.000x, note that these structures are more open (unrolled), according to Steibel (2008), these structures that store surfactant unwind to take the form of tubular myelin, whose function is to reduce the surface tension of the pulmonary alveoli. (B) Presence of lamellar bodies in the amniotic fluid of sheep belonging to Group II (Caesarean section), in an increase of 120.000x, observe the lamellar bodies in a small amount, still coiled, showing their concentric blades. (C) Lamellar body belonging to Group III (cesarean section + dexamethasone), in an increase of 50.000x, showing its concentric blades, represented by a thin layer of reduced diameters, accompanied by a center in its structure.' 
Table 3. Median (Md), minimum and maximum percentages of blue and orange stained cells present in the amniotic fluid of ewes from Group I (born naturally), Group II (caesarean) and Group III (caesarean + dexamethasone), using Nile blue (0.1\%) and hematoxylin-Shorr

\begin{tabular}{|c|c|c|c|c|c|c|c|c|c|c|}
\hline \multirow{2}{*}{ Variable } & \multirow{2}{*}{ Category } & \multicolumn{3}{|c|}{ Group I } & \multicolumn{3}{|c|}{ Group II } & \multicolumn{3}{|c|}{ Group III } \\
\hline & & $\mathrm{n}$ & $\mathrm{Md}$ & Min - Max & $\mathrm{n}$ & $\mathrm{Md}$ & Min - Max & $\mathrm{n}$ & $\mathrm{Md}$ & Min - Max \\
\hline \multirow[t]{2}{*}{ Nile blue staining } & Blue & 10 & $96.1^{\mathrm{A}}$ & $84.0-98.0$ & 11 & $90.5^{\mathrm{AB}}$ & $73.0-96.3$ & 11 & $87.0^{\mathrm{B}}$ & $80.8-96.9$ \\
\hline & Orange & 10 & $4.0^{\mathrm{A}}$ & $2.0-16.0$ & 11 & $9.5^{\mathrm{AB}}$ & $3.7-27.0$ & 11 & $13.0^{\mathrm{B}}$ & $3.1-19.3$ \\
\hline \multirow[t]{2}{*}{ Hematoxilin-Shorr } & Blue & 10 & $21.0^{\mathrm{A}}$ & $8.0-42.7$ & 11 & $40.0^{\mathrm{AB}}$ & $19.8-66,7$ & 11 & $45.6^{\mathrm{B}}$ & $32.0-64.9$ \\
\hline & Orange & 10 & $79.0^{A}$ & $57.3-92.0$ & 11 & $60.0^{\mathrm{AB}}$ & $33.3-80.2$ & 11 & $54.4^{\text {B }}$ & $35.1-68.0$ \\
\hline
\end{tabular}

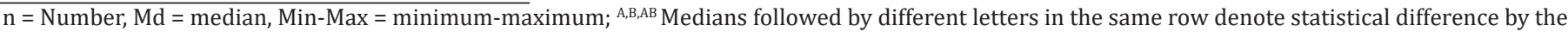
Dunn test $(p<0.05)$.

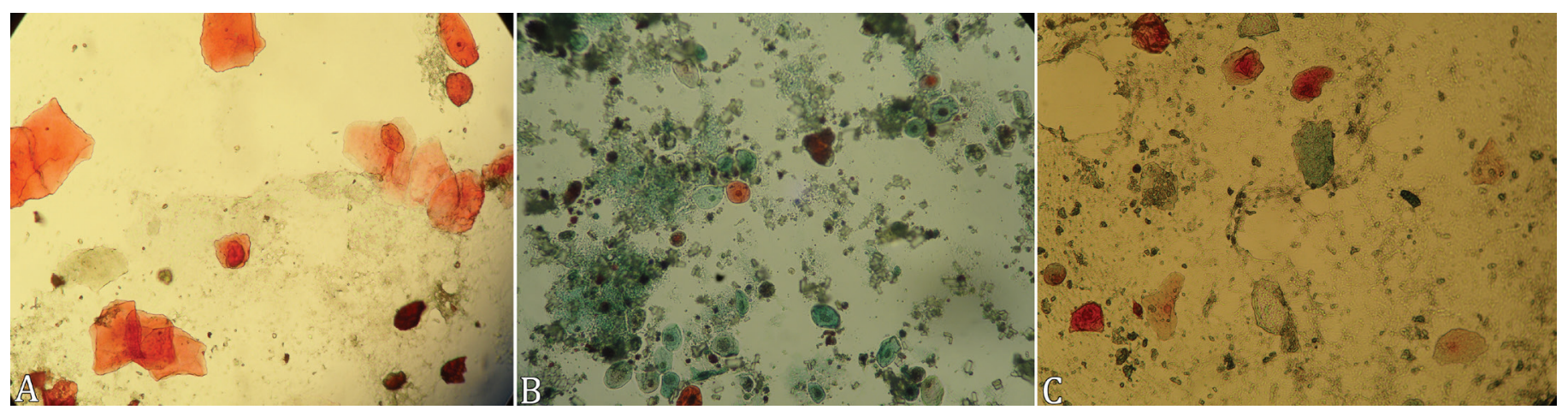

Fig.4. (A) Blade belonging to Group I (born naturally), showing reater presence of orangeophilic cells. In this figure the highest incidence is anucleated superficial cells. Hematoxylin-Shorr, obj.40x. (B) Blade belonging to Group II (Caesarean section), showing a greater amount of cyanophilic cells (blue /green) than orangeophilic cells. Hematoxylin-Shorr, obj.40x.(C) Blade belong to Group III (cesarean section + dexamethasone), showing the presence of orangeophilic as well as cyanophilic cells, indicating that the application of dexamethasone caused greater fetal maturity when compared to Group II that did not receive dexamethasone. Hematoxylin-Shorr, obj.40x.

\section{DISCUSSION}

The normal gestation period among sheep varies both between breeds and individual sheep. Breeds that mature early or are prolific tend to have shorter gestation periods when compared to the slower maturing wool breeds of sheep. The average length of gestation is 150 days, with a standard variation of 13 days between individuals. In this study, lambs were considered premature when born by cesarean section at 138 days gestation (Edmondson et al. 2012).

Adequate Apgar scores in the immediate neonatal period (Table 1) vary among domestic species (Carrillo et al. 1997). About the results of Adequate Apgar scores in the immediate neonatal period, While the median score of Group III lambs was not significantly higher than that in Group II, there was a slight increase in the Apgar score of Group I at birth (T0). Presumably, this was due to the administration of dexamethasone in these ewes 36 hours prior to the caesarean section being conducted. In a study on canine neonates, a positive correlation between Apgar scores and the formation of septa and subsaccules in the lungs was found. This clinical improvement may be due to more efficient gas exchange from structural changes in the lung parenchyma due to administration of antenatal glucocorticoids (Regazzi 2011).

Regarding the mortality rate, despite not differing statistically, the percentage of deaths was higher in animals born in Group II than in Group III, assuming that lambs born in both groups were premature (born at 138 days). It is believed that greater survival in Group III probably occurred due to the administration of dexamethasone in the sheep 36 hours before farrowing. It is known that the administration of corticosteroids has positive effects on fetal lung maturation, decreasing the risk of premature births, respiratory distress syndrome (RDS), and other gestational changes (Areia et al. 2018).

Avila et al. (2014) showed that the administration of glucocorticoids, such as dexamethasone, efficiently decreased the mortality rate in premature lambs born at 138 days of life, as it improved the clinical condition and survival of these lambs.

Radiography is a cheap and effective method for visualizing lung changes. It is a complementary examination that helps in the diagnosis of the patient.

The ultrasound of the lung, although it is a relatively new technique, imaging diagnosis using ultrasound of the lung is valuable in predicting newborn respiratory prognosis. Research conducted on humans provides evidence that the analyses of lung ultrasound images can help predict neonatal respiratory morbidity (Bonet-Carne et al. 2015).

The Clements' test showed if a test result is positive, the fetal lung is considered mature (Crockett 1988); however, Clements' test has a high rate of false negative results. Therefore, it is recommended that negative Clements' test results should be reviewed with caution and, where possible, other methods of assessing fetal lung maturity, such as cytological evaluation by hematoxylin-Shorr staining, should be used to confirm the parameters of neonatal viability. A previous study conducted reported that all $\mathrm{AF}$ samples obtained from ewes showed little reaction to the Clements' test and were, therefore, considered negative (Souza et al. 2000). This demonstrates the lack of accuracy of this technique when it is applied to ewes and/ or there is an absence of surfactant at the corresponding gestational stages in sheep. 
In humans, the size of the LB $(0.2-2 \mu \mathrm{m})$ is compatible

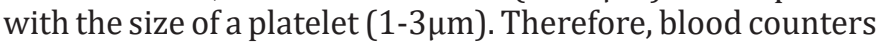
commonly used to perform complete blood counts can quantify LB. The number corresponding to the platelet count is considered the total quantity of LB. However, due to several unsatisfactory attempts to undertake LB counts using standard hematological counters as well as the lack of studies in this area regarding sheep, we also used transmission electron microscopy (TEM) to evaluate LB in AF. Lamellar bodies can be easily detected in AF through using electron microscopy (Fig.3). Several studies have shown that LB increases over the course of pregnancy and its presence in AF correlates well with other indicators of fetal lung maturity (Lee et al. 1996, DeRoche et al 2002, Castagnetti et al. 2007, Jörger et al. 2017).

Using the Nile blue technique, the cells from amniotic fluid were classified as cyanophilic cells (blue cells) with characteristics of fetal immaturity, as well as the presence of orange cells (orange-colored cells) where their presence is an indicative of fetal maturity. In this study it was observed a larger amount of cyanophilic cells (blue) when compared to orangeophilic cells (orange), with medians of $96.1 \%$ in Group I, 90,5\% in Group II and $87 \%$ (Group III). Such, these results could be explained by the fact that animals from Groups II and III born by performing elective surgeries at 138 days of age, which would indicate a larger off cells indicative of fetal immaturity. However, when the normal delivery group (Group I) was similar results of those of premature animals, with few orange cells and many blue cells. Therefore, we conclude that in this method most cells stained blue, making this technique unsatisfactory in sheep species. So it was proposed in this research the cytology of Hematoxylin- Shorr described by Moya (2005), for evaluation and comparison results obtained between both techniques. We can see that in Groups II and III, while orangeophilic cells decreased when compared to Group I, cyanophilic cells increased in these two groups, since cyanophilic cells are indicative of fetal immaturity, that is, it becomes the expected result, since these lambs were born premature in Groups II and III. Based on our findings, we believe that cytological study of AF by hematoxylin-Shorr staining should be done for assessing fetal maturity as it is comparatively low-cost, reliable, and easy to perform.

\section{CONCLUSIONS}

The assessment of pulmonary and fetal maturity is important in veterinary neonatology so as to predict when a high-risk patient will give birth as well as to enable faster administration of therapy to newborns requiring treatment, helping to increase their survival rates.

Clements' test is inconsistent and unreliable when negative results are obtained, although it is reliable when positive results are obtained and can be used as a strong indicator of lung maturation in newborns. The use of transmission electron microscopy reveals that lamellar bodies in amniotic fluid of sheep ranged from 0.019 to $0.590 \mu \mathrm{m}$. Therefore, platelet channel of hematology analyzers is not an accurate method to obtain results regarding the amount of LB in sheep. Nile blue staining $(0.1 \%)$ is not satisfactory in this species for predicting fetal maturity. However, hematoxylin-Shorr staining is effective and can accurately predict the degree of maturity of fetal lambs, especially when it is applied together with other assessment techniques used for evaluating fetal and lung maturity. Radiographic findings play an important role in assessing pulmonary maturity and physiologic condition of premature lambs.

Acknowledgments.- The authors would like to thank the staff of the Department of Electron Microscopy, “Faculdade de Ciências Agrárias e Veterinárias”, Unesp, Jaboticabal/SP, the "Departamento de Biologia Celular e Molecular e Bioagentes Patogênicos” (Biocel), "Faculdade de Medicina”, USP, RibeirãoPreto/SP, and the "Fundação de Amparo à Pesquisa do Estado de São Paulo" (FAPESP) for granting a master's scholarship (2011/14933-3) and financial support (2011/20219-1).

Declaration of conflict of interest.- The authors declare no conflicts of interest.

\section{REFERENCES}

Agrons G.A, Courtney S.E., Stocker T. \& Markowitz I. 2005. Lung disease in premature neonates: radiologic-pathologic correlation 1. Radiographics 25(4):1047-1073. <https://dx.doi.org/10.1148/rg.254055019>

Areia A.L., Almeida M.F., Braga A.J.C., Pereira N.B., Macedo C.V. \& NogueiraSilva C. 2018. Corticoterapia para maturação pulmonar fetal. Acta Obst. Ginecol. Port. 12(4):311-313.

Avila G.L., Bovino F., Camargo D.G., Souza N.C., Santos G.G.F., Deschk M., Mendes L.C.N. \& Feitosa F.L.F. 2014. Aplicação materna de glicocorticóide nos parâmetros vitais de cordeiros nascidos a termo e prematuros. Ciência Rural 44(6):1106-1112. <https://dx.doi.org/10.1590/S010384782014000600025>

Bonet-Carne E., Palacio M., Cobo T., Perez-Moreno A., Lopez M., Piraquive J.P., Ramirez J.C., Botet F., Marques F. \& Gratacos E. 2015. Quantitative ultrasound texture analysis of fetal lungs to predict neonatal respiratory morbidity. Ultrasound Obstet. Gynecol. 45(4):427-433. <https://dx.doi. org/10.1002/uog.13441><PMid:24919442>

Born E. 1981. Untersuchungen über den einfluss der schnittentbindung auf die vitalität neugeborener kälber. Doctoral Dissertation, Tierärztliche Hochschule, Hannover. 47p.

Bovino F. 2015. Abordagem clínica de cordeiros prematuros: avaliação de protocolos terapêuticos emergenciais para estimulação da atividade respiratória. Doctoral Dissertation, Faculdade de Medicina Veterinária de Araçatuba, Universidade Estadual Paulista. 93p.

Brosens I. \& Gordon H. 1966. The estimation of maturity by cytological examination of the liquor amnii. J. Obstet. Gynecol. 73(1):88-90. <https:// dx.doi.org/10.1111/j.1471-0528.1966.tb05124.x><PMid:4159951>

Carrillo J.B., García E.A., Lozano C.G., Galache P.V., Lozano de la J.G. \& González H.L. 1997. Cuantificación de cuerpos lamelares en líquido amniótico: método de valoración de madurez pulmonar fetal. Ginecol. Obstet. Mex. 65:202-206.

Castagnetti C., Mariella J., Serrazanetti G.P., Grandis A., Merlo B., Fabbri M. \& Mari G. 2007. Evaluation of lung maturity by amniotic fluid analysis in equine neonate. Theriogenology 67(9):1455-1462. <https://dx.doi. org/10.1016/j.theriogenology.2007.02.013><PMid:17448529>

Cheong J.L.Y., Lee K.J., Boland R.A., Spittle A., Opie G.F., Burnett A.C., Hickey L.M., Roberts G., Anderson P.J. \& Doyle L.W. 2018. Changes in long-term prognosis with increasing postnatal survival and the occurrence of postnatal morbidities in extremely preterm infants offered intensive care: a prospective observational study. Lancet Child Adolesc. Health 2(12):872879. <https://dx.doi.org/10.1016/s2352-4642(18)30287-6>

Clements J.A., Platzker A.C.G., Tierney D.F., Hobel C.J., Creasy R.K., Margolis A.J., Thibeault D.W., Tooley W.H. \& Willian O.H. 1972. Assessment of the risk of respiratory-distress syndrome by a rapid test for surfactant in amniotic fluid. N. Engl. J. Med. 286(20):1077-1082. <https://dx.doi.org/10.1056/ NEJM197205182862004><PMid:5067186>

Crockett H.H. 1988. A comparison of laboratory tests for assessing fetal maturity. Master's Thesis, University of Utah, Salt Lake City, UT. 
DeRoche M.E., Ingardia C.J., Guerette P.J., Wu A.H., LaSala C.A. \& Mandavilli S.R. 2002. The use of lamellar body counts to predict fetal lung maturity in pregnancies complicated by diabetes mellitus. Am. J. Obstet. Gynecol. 187(4):908-912. <https://dx.doi.org/10.1067/mob.2002.127122> $<$ PMid:12388975>

Dubin S.B. 1998. Assessment of fetal lung maturity: practice parameter. Am. J. Clin. Pathol. 110(6):723-732.<https://dx.doi.org/10.1093/ajcp/110.6.723> <PMid:9844584>

Edmondson M.A., Roberts J.F., Baird A.N., Bychawski S. \& Pugh D.G. 2012. Theriogenology of sheep and goats. Sheep Goat Med. 150-230. <https://dx.doi.org/10.1016/b978-1-4377-2353-10008-3>

Fakhoury G., Daikoku N.H., Benser J. \& Dubin N.H. 1994. Lamellar body concentrations and the prediction of fetal pulmonary maturity. Am. J. Obstet. Gynecol. 170(1):72-76. <https://dx.doi.org/10.1016/S00029378(13)70282-5>

Feitosa F.L.F., Ávila L.G., Bovino F., Santos G.G.F., Mendes L.C.N., Peiró J.R. \& Perri S.H.V. 2017. Efeitos da corticoterapia maternal nos valores hemogasométricos de cordeiros nascidos a termo e prematuros. Pesq. Vet. Bras. 37(5):521-525. <https://dx.doi.org/10.1590/s0100-736x2017000500016>

Feitosa F.L.F., Braga G.I., Mendes L.C.N., Alcindo J.F., Souza N.C., Bovino F., Trein T.A., Trevizan J.T. \& Baptista R.S. 2020. Avaliação da maturidade pulmonar de cabritos nascidos a termo e prematuros. Arq. Bras. Med. Vet. Zootec. 72(4):1313-1320. <https://dx.doi.org/10.1590/1678-4162-11522>

Ghartey K., Coletta J., Lizarraga L., Murphy E., Ananth C.V. \& Bannerman C.G. 2012. Neonatal respiratory morbidity in the early term delivery. Am. J. Obstet. Gynecol. 207(4):292.e1-292.e4. <https://dx.doi.org/10.1016/j. ajog.2012.07.022><PMid:22902075>

Harrison S.M. \& Goldenberg R.L. 2016. Global burden of prematurity. Seminars Fetal Neonatal Med. 21(2):74-79. <https://dx.doi.org/10.1016/j. siny.2015.12.007><PMid:26740166>

Jainudeen M.R. \& Hafez E.S.E. 2004. Gestação, fisiologia pré-natal e parto, p.141-155. In: Hafez B. \& Hafez E.S.E. (Eds), Reprodução Animal. 7a ed. Manole, Barueri.

Jörger A., Acevedo C., Busley D., Ganter M., Schmiedl A. \& Ziehank E.H. 2017. Stereological and biophysical characteristics of the ovine surfactant system and its changes caused by ovine pulmonary adenocarcinoma. Res. Vet. Sci. 114:332-340. <https://dx.doi.org/10.1016/j.rvsc.2017.06.008> <PMid:28651195>

Kjeldsberg C. \& Knight J. 1998. Body fluids: laboratory examination of amniotic, cerebrospinal, serous and synovial fluids. 3rd ed. American Society of Clinical Pathologists, Chicago.

Lee I.S., Cho Y.K., Kim A., Min W.K., Kim K.S. \& Mok J.E. 1996. Lamellar body count in amniotic fluid as a rapid screening test for fetal lung maturity. J Perinatol. 16(Pt 1):176-180. <PMid:8817425>
Lewis P.S., Lauria M.R., Dzieczkowski J., Utter G.O. \& Dombrowski M.P. 1999. Amniotic fluid lamellar body count: Cost-effective screening for fetal lung maturity. Obstet. Gynecol. 93(3):387-391. <https://dx.doi.org/10.1016/ s0029-7844(98)00416-5><PMid:10074985>

Luna L.G. 1968. Manual of histologic staining methods of the Armed Forces Institute of Pathology. 3rd ed. McGraw-Hill Book Company, New York. 258p.

Miron P.M. 2012. Preparation, culture and analysis of amniotic fluid samples. Curr. Protocols Humans Genet. 74(1):e62. <https://dx.doi. org/10.1002/0471142905.hg0804s74 ><PMid:22786614>

Miura H., Yamazaki T., Kikichi M. \& Sakaguchi M. 2019. Plasma steroid hormone concentrations and their relationships in Suffolk ewes during gestation and parturition. Anim. Sci. J. 90(11):1426-1431.<https://dx.doi. org/10.1111/asj.13286><PMid:31486265>

Morrison J.C. 1974. Nile blue staining of cells in amniotic fluid for fetal maturity. Part I: a reppraisal. Obstet. Gynecol. 44(3):355-361. <PMid:4137082>

Moya C.F. 2005. Tipificação citológica do líquido amniótico de bezerros oriundos de produção In Vitro, transferência de embrião e inseminação artificial no momento do parto. Master's Thesis, Faculdade de Medicina Veterinária e Zootecnia, Universidade Estadual Paulista, Botucatu, SP. 64p.

Patel R.M. 2016. Short-and-long-term outcomes for extremely preterm infants. Am. J. Perinatol. 33(3):318-328. <https://dx.doi.org/10.1055/s-0035-1571202> $<$ PMid:26799967>

Radostits O.M., Gay C.C., Hinchcliff K.W. \& Constable P.D. 2007. Veterinary Medicine: a textbook of the diseases of cattle, horses, sheep, pigs and goats. 10th ed. Elsevier Saunders, Philadelphia. 2156p.

Regazzi F.M. 2011. Modificações pulmonares morfométricas e funcionais de neonatos da espécie canina em resposta à corticoterapia pré-natal. Master[]s Thesis, Faculdade de Medicina Veterinária e Zootecnia, Universidade Estadual Paulista, Botucatu, SP. 106p.

Rodrigues J.A., Veiga G.A.L., Silva L.C., Lúcio C.F. \& Vannuchi C.I. 2007. Avaliação por escore apgar, temperatura e hemogasometria arterial em neonatos da espécie ovina. Annals of Congresso Brasileiro de Reprodução Animal, Curitiba, p.23.

Rosborg J. 1970. Estimation of fetal maturity by amniotic fluid cytology. Acta Obstet. Gynecol. Scand. 49(3):285-287. <https://dx.doi. org/10.3109/00016347009157252><PMid:4103880>

Souza C., Prestes N.C. \& Lopes R.S. 2000. Determinação da maturidade fetal através da análise de parâmetros físicos e bioquímicos do fluido amniótico de ovinos (Ovis aries), colhidos em abatedouro. Annals of XXVII Congresso Brasileiro de Medicina Veterinária. Águas de Lindoia, SP, p.29a.

Tibary A. \& Van Metre D. 2004. Surgery of the sheep and goat reproductive system and urinary tract, p.527-547. In: Fubini S.L. \& Ducharme N.G (Eds), Farm Animal Surgery. W.B. Saunders, St. Louis. 